\title{
161. Differentiation during Cleavage in Xenopus laevis. I
}

\author{
Acquisition of Self-differentiation Capacity of \\ the Dorsal Marginal Zone
}

\author{
By Osamu Nakamura, Hiroko TaKasaki, \\ and Tomihiro Mizohata \\ Department of Biology, Osaka Kyôiku University, Osaka \\ (Comm. by Yô K. OKada, M. J. A., Sept. 12, 1970)
}

It has recently been found that in urodele embryos the dorsal marginal zone, destined to become the organizer, acquires its particular capacity of induction and self-differentiation during cleavage, namely between stages 7 and 9. (Nakamura and Matsuzawa 1967; Nakamura 1968; Nakamura and Takasaki 1970). Acquisition of these unique properties is itself a type of epigenetic differentiation, though it is not visible morphologically. This means that differentiation proceeds during cleavage, keeping pace with cell-proliferation.

Hitherto, most experiments on the problems of differentiation have been carried out with amphibian embryos after the onset of gastrulation. However, it now seems of interest to study the same problems with embryos during cleavage. For studies on the exact time relations of processes, urodele embryos are very suitable material because of their slower development, but for biochemical investigations on factors initiating and promoting differentiation during cleavage, they are unsuitable because large samples are not available. For this purpose, anuran embryos are more suitable since a great number of embryos can be obtained from one batch of eggs. Thus, we have newly adopted Xenopus laevis embryos as a main material.

First we repeated the experiments we had previously performed on Triturus morulae (Nakamura and Takasaki 1970) with Xenopus embryos to test the self-differentiation capacity of the dorsal marginal zone in the morula and blastula. The material used ranged from st. 6 to st. 9 of Nieuwkoop and Faber (1956). The areas illustrated in Fig. 1 were cut out and cultured separately, without any kind of envelope or covering, in Holtfreter's saline modified by addition per liter of $10^{5}$ unit of crystalline potassium penicillin $\mathrm{G}$ and $0.5 \mathrm{~g}$ each of streptomycin sulfate and crystalline dehydrostreptomycin sulfate, adjusting the $\mathrm{pH}$ to 7.3 with Tris-HCl buffer solution. The operation and culture room was maintained at $20 \pm 1^{\circ} \mathrm{C}$. After 48 hour's culture, serial sections of specimens counter-stained with borax-carmine and picroblauschwarz were examined microscopically. 


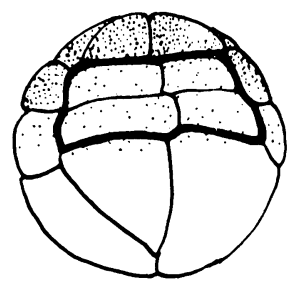

St. 6

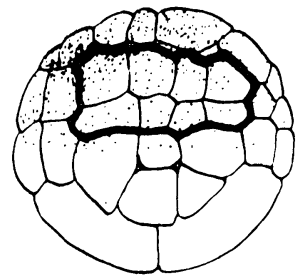

St. $6 \frac{1}{2}$

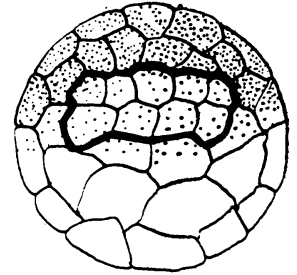

St. 7

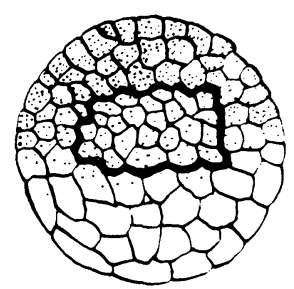

St. 8

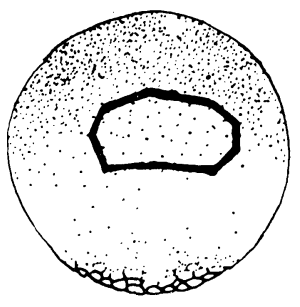

St. 9

Fig. 1. Areas cut out and cultured.

Table I. Frequencies of differentiation occurred in explants of the dorsal marginal zone

\begin{tabular}{|c|c|c|c|c|c|c|c|c|c|}
\hline \multirow[b]{3}{*}{ Stages } & \multicolumn{6}{|c|}{ Mesodermal } & \multicolumn{2}{|c|}{ Ectodermal } & \multirow{3}{*}{ 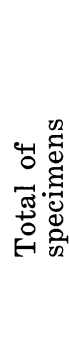 } \\
\hline & 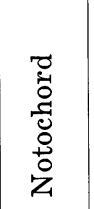 & 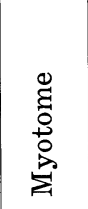 & 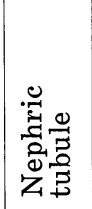 & 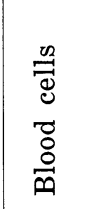 & 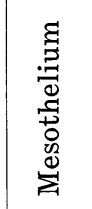 & 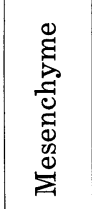 & 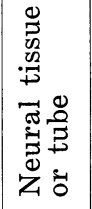 & 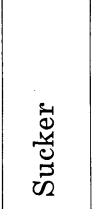 & \\
\hline & $\begin{array}{l}\text { No. } \\
(\%)\end{array}$ & $\begin{array}{l}\text { No. } \\
(\%)\end{array}$ & $\begin{array}{l}\text { No. } \\
(\%)\end{array}$ & $\begin{array}{l}\text { No. } \\
(\%)\end{array}$ & $\begin{array}{l}\text { No. } \\
(\%)\end{array}$ & $\begin{array}{l}\text { No. } \\
(\%)\end{array}$ & $\begin{array}{l}\text { No. } \\
(\%)\end{array}$ & $\begin{array}{l}\text { No. } \\
(\%)\end{array}$ & \\
\hline St. 6 & $\left(\begin{array}{c}1 \\
5.0\end{array}\right)$ & $\begin{array}{c}1 \\
(5.0)\end{array}$ & $\begin{array}{l}0 \\
0 \text { ) }\end{array}$ & $\begin{array}{c}3 \\
(15.0)\end{array}$ & $\begin{array}{c}4 \\
(20.0)\end{array}$ & $\begin{array}{l}0 \\
0)\end{array}$ & $\begin{array}{c}1 \\
(5.0)\end{array}$ & $\begin{array}{c}5 \\
(25.0)\end{array}$ & $\begin{array}{c}20 \\
(100)\end{array}$ \\
\hline St. $6 \frac{1}{2}$ & $\begin{array}{c}11 \\
(45.8)\end{array}$ & $\begin{array}{c}6 \\
(25.0)\end{array}$ & $\begin{array}{c}1 \\
(4.2)\end{array}$ & $\begin{array}{c}11 \\
(45.8)\end{array}$ & $\begin{array}{c}13 \\
(54.2)\end{array}$ & $\begin{array}{c}8 \\
(33.3)\end{array}$ & $\begin{array}{c}12 \\
(50.0)\end{array}$ & $\begin{array}{c}9 \\
(37.5)\end{array}$ & $\begin{array}{c}24 \\
(100)\end{array}$ \\
\hline St. 7 & $\begin{array}{c}18 \\
(78.3)\end{array}$ & $\begin{array}{c}14 \\
(60.9)\end{array}$ & $\left(\begin{array}{c}2 \\
(8.8)\end{array}\right.$ & $\begin{array}{c}10 \\
(43.5)\end{array}$ & $\begin{array}{c}10 \\
(43.5)\end{array}$ & $\begin{array}{c}18 \\
(78.3)\end{array}$ & $\begin{array}{c}13 \\
(56.5)\end{array}$ & $\begin{array}{c}7 \\
(30.4)\end{array}$ & $\begin{array}{c}23 \\
(100)\end{array}$ \\
\hline St. 8 & $\begin{array}{c}12 \\
(92.3)\end{array}$ & $\begin{array}{c}12 \\
(92.3)\end{array}$ & $\left(\begin{array}{c}2 \\
(15.4)\end{array}\right.$ & $\begin{array}{c}5 \\
(38.5)\end{array}$ & $\begin{array}{c}6 \\
(46.2)\end{array}$ & $\begin{array}{c}5 \\
(38.5)\end{array}$ & $\begin{array}{c}8 \\
(61.5)\end{array}$ & $\left(\begin{array}{c}1 \\
7.7\end{array}\right)$ & $\begin{array}{c}13 \\
(100)\end{array}$ \\
\hline St. 9 & $\begin{array}{c}12 \\
(92.3)\end{array}$ & $\begin{array}{c}12 \\
(92.3)\end{array}$ & $\begin{array}{c}3 \\
(23.1)\end{array}$ & $\begin{array}{c}4 \\
(30.8)\end{array}$ & ${ }^{8}$ & $\begin{array}{c}5 \\
(38.5)\end{array}$ & $\begin{array}{c}12 \\
(92.3)\end{array}$ & $\left(\begin{array}{c}2 \\
(15.4)\end{array}\right.$ & $\begin{array}{c}13 \\
(100)\end{array}$ \\
\hline
\end{tabular}


Results. The kinds of tissues developed in explants and their frequencies of occurrence are summarized in Table I and shown graphically in Fig. 3.

Embryos at st. 6 were composed of 32 blastomeres which were so extensive that some of them contained, in a single cell, the presumptive material for both ectoderm and mesoderm. Blastomeres of such dual nature were frequent in the pieces taken at this stage, as shown in Fig. 1a. Moreover, operation was quite difficult, the embryos being still flaccid. Differentiation of axial organs was very poor (Fig. 2a) and notochord, somite and neural tissue were found in only one of 20 specimens in a rudimentary state. Some explants produced mesothelium, blood cells and sucker (Fig. 2b), but none of them were special products of the dorsal marginal zone in normal development.

In contrast, axial organs differentiated fairly well in the pieces taken from embryos at st. 61/2 (Fig. 2c). Notochord and neural tissue developed in about half the specimens, and myotomes in a quarter of them. Most cells of the notochord were highly vacuolated. The mesothelium and blood cells were also found in about half the specimens and the mesenchyme in one third. Pronephric tubules were detected in only one case. The surface of all transplants was covered with typical epidermis, which was in a little more than one third of the specimens developing into a sucker.

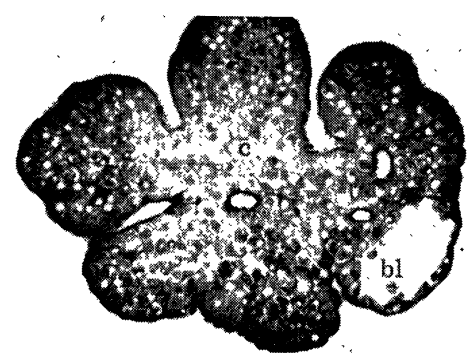

a

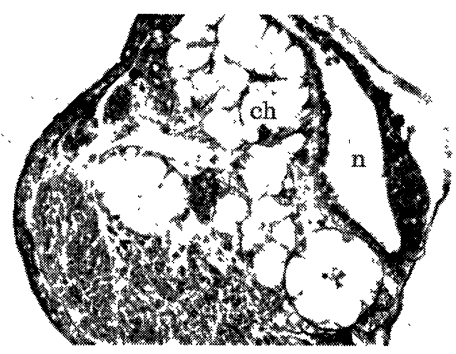

c

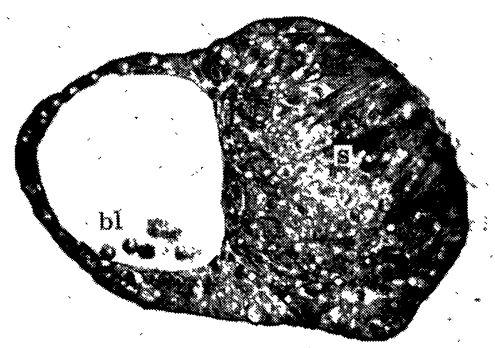

b

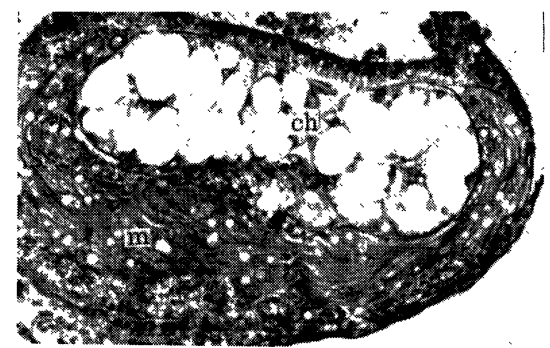

d

Fig. 2. Microphotographs of representative explants at stages of (a) (b) St. 6, (c) St. $6 \frac{1}{2}$ and (d) St. 8. bl: primordial blood cells, c: undifferentiated cell mass, ch: notochord, $\mathrm{m}$ : muscle, $\mathrm{n}$ : neural tube, $\mathrm{s}$ : sucker. 
Explantation at st. 7 resulted in more frequent formation of notochord and myotomes, the former appearing in nearly $80 \%$, and the latter in over $60 \%$ of the total specimens. Muscular cells in the myotome showed marked striation.

In explants at st. 8, myotomes as well as notochord developed in almost all specimens. Neural tissue also appeared in a little over $60 \%$ of them. Histological differentiation of these axial organs was far advanced (Fig. 2d). On the contrary, sucker was found in only one specimen and was so poorly differentiated that it was scarcely recognizable as such.

In most explants at st. 9, not only notochord and myotomes, but also neural tube developed. The surface of explants became covered partly with mesothelium and partly with epidermis. Sucker was formed in only two specimens in which histological differentiation of other tissues was greatly reduced.

Discussion and conclusions. As stated above, axial organs were produced in only one of 20 explants of the dorsal marginal zone at st. 6. The low frequency of their development does not seem due to the culture conditions, because in specimens cultured under the same conditions sucker developed as frequently as in explants taken at later stages. It seems likely that the dorsal marginal zone of Xenopus embryo at st. 6 usually lacks the capacity to give rise to axial organs independently. The exceptional explant which produced axial organs was probably taken from an embryo which developed prematurely.

The capacity to develop independently into mesodermal axial organs becomes conspicuous at st. 61/2, and at the next stage, it was recognized in a majority of specimens, and at st. 8 in almost all embryos. Thus, in Xenopus embryos, too, the dorsal marginal zone acquires its particular capacity for self-differentiation into meso-

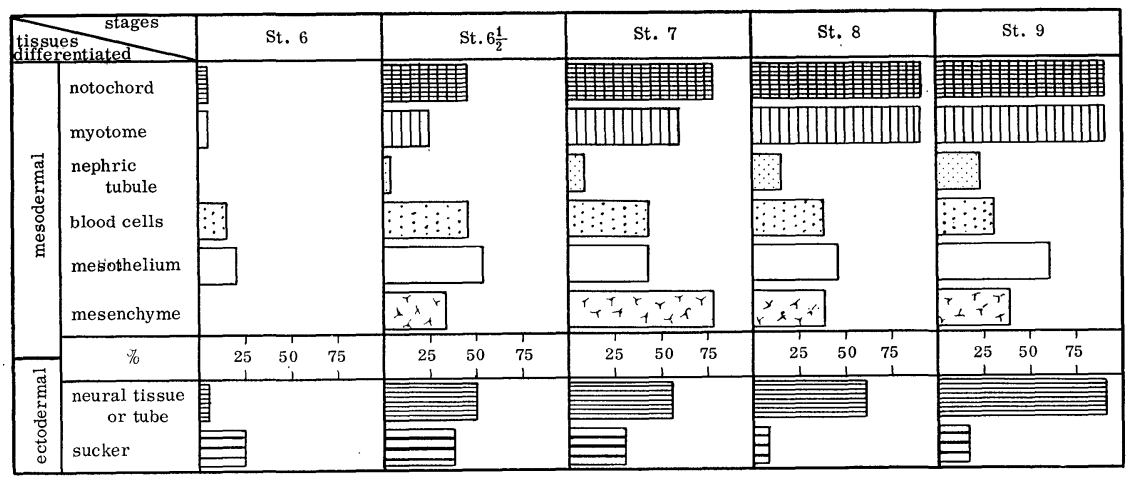

Fig. 3. Frequency diagram of occurrence of tissues in the explants at 5 stages tested in Xenopus laevis. 
dermal axial organs epigenetically during cleavage; between st. $61 / 2$ and st. 8, that is a little earlier than in Triturus embryos.

Recently, rapid synthesis of 'heterogeneous' RNA starting at st. 7 (Bachvarova et al. 1966; Woodland and Gurdon 1968) and new synthesis of sRNA initiating at st. 8 (Brown and Littna 1964; Shiokawa and Yamana 1965; Bachvarova et al. 1966; Gurdon 1967; Woodland and Gurdon 1968) have been detected in embryos of the same species. Comparing with the present results, these synthesis seem to take place after the first appearance of the capacity for selfdifferentiation of the marginal zone. If it is really the case, they may be consequences rather than causal factors of the aquisition of this capacity. However, this is uncertain, especially as RNA was measured using a sample prepared from a number of embryos. At st. 61/2, the differentiation capacity appeared only in a half or less of tested embryos and exclusively in blastomeres in the marginal zone. Even if some kinds of RNA were newly synthesized in these blastomeres, it is doubtful whether they could be detected as a 'rapid increase' of RNA in the sample. On the other hand, the percentage of embryos with the differentiation capacity increased rapidly from st. 7 to st. 8 . This increase is parallel with the rapid synthesis of 'heterogeneous' RNA. Studies are now in progress on the relation between RNA synthesis and the aquisition of self-differentiation capacity, which in part have been preliminarily reported (Nakamura et al. 1965, 1967; Nakamura 1967, 1968).

Mesodermal tissues other than notochord and myotomes also differentiated in explants at st. 9. This fact suggests that, as discussed previously (Nakamura and Matsuzawa 1967), at this stage the dorsal marginal zone is a complex of cells with varying morphogenetic potentials. Similar observations at more advanced stages have been reported by Holtfreter (1938) with early gastrulae and by Yamada (1940) with early neurulae of urodeles.

Neural tissues were probably induced by mesodermic cells from cells with ectodermic potency in explants. The present results, however, do not show when the inducing power comes into effect during culture, and further studies on this problem will be reported shortly.

Summary. 1) The dorsal marginal zone of Xenopus laevis embryos at st. $6,61 / 2,7,8$ and 9 was dissected out and cultured in vitro.

2) At st. 6, only one explant, presumably taken from an unusually premature embryo, developed into axial organs, some other specimens forming sucker.

3) The capacity for self-differentiation of the zone into mesodermal axial organs becomes conspicuous at st. 61/2. Embryos with this capacity increases at st. 7 and come to the full at st. 8 . 
4) It is concluded that, as in Triturus, the capacity for selfdifferentiation of the dorsal marginal zone is not preexistent in Xenopus embryos but is aquired during cleavage; i.e. at st. $61 / 2$ to st. 8 , a little earlier than in Triturus.

5) The first appearance of this capacity precedes the rapid synthesis of "heterogeneous" RNA recently reported, while the rapid increase in the percentage of embryos with this capacity during st. 7 and st. 8 is parallel with the latter.

\section{References}

Bachvarova, R., Davidson, E. H., Allfrey, V. G., and Mirsky, A. E. (1966): Activation of RNA synthesis associated with gastrulation. Proc. Natn. Acad. Sci. U.S.A., 55, 358-65.

Brown, D. D., and Littna, E. (1964): Variations in the synthesis of stable RNA's during oogenesis and development in Xenopus Laevis. J. molec. Biol., 8, 688-95.

(1966): Synthesis and accumulation of low molecular weight RNA during embryogenesis of Xenopus laevis. J. Molec. Biol., 20, 95-112.

Gurdon, J. B. (1967): Control of gene activity during the early development of Xenopus laevis. In Heritage from Mendel (ed. R. A. Brink), 203-41. University of Wisconsin Press.

Nakamura, O. (1967): How does the organizer itself get organized? (in Japanese with English abstract). Jap. J. Exp. Morph., 21, 256-75.

- (1968): Differentiation during cleavage and nucleocytoplasmic interactions. Ann. d'Embryol. Morph., Suppl., 1, 261-62.

Nakamura, O., Hayakawa, H., and Yamamoto, K. (1965): Cytodifferentiation and nucleocytoplasmic interactions during cleavage (in Japanese). Zool. Mag., 74, 341 .

Nakamura, O., Hayakawa, H., Yamamoto, K., Handa, S., Isoya, T., Sunomata, Y., and Nakayama, F. (1967): Cytodifferentiation and nucleocytoplasmic interactions during cleavage. II (in Japanese). Jap. J. Exp. Morph., 21, 485.

Nakamura, O., and Matsuzawa, T. (1967): Differentiation capacity of the marginal zone in the morula and blastula of Triturus pyrrhogaster. Embryologia, $\mathbf{9}, 223-37$.

Nakamura, O., and Takasaki, H. (1970): Further studies on the differentiation capacity of the dorsal marginal zone in the morula of Triturus pyrrhogaster. Proc. Japan Acad., 46, 546-51.

Nieuwkoop, P. D., and Faber, J. (1956): Normal table of Xenopus laevis (Daudin). Amsterdam: North Holland Publishing Company.

Shiokawa, K., and Yamana, K. (1965): Demonstration of "polyphosphate" and its possible role in RNA synthesis during early development of Rana japonica embryos. Expl. Cell Res., 38, 180-6.

Woodland, H. R., and Gurdon, J. B. (1968): The relative rate of synthesis of DNA, sRNA and rRNA in the endodermal region and other parts of Xenopus laevis embryos. J. Embryol. Exp. Morph., 19, 363-85. 